\title{
Environmental Quality and Fish Communities in Selected Catchments of Lake Victoria
}

\author{
Fredrick Jones Muyodi ${ }^{\mathrm{a}, *}$, Fredrick L. Mwanuzi ${ }^{\mathrm{b}}$ and Raphael Kapiyo ${ }^{\mathrm{c}}$ \\ a Department of Zoology, Makerere University, P.O. Box 7062, Kampala, Uganda. \\ ${ }^{b}$ University of Dares Salaam, Tanzania \\ ${ }^{c}$ Maseno University, Maseno, Kenya.
}

\begin{abstract}
Water quality and fish species are studied in selected catchments of Lake Victoria. The major aim of the study is to establish the relationship between the environmental quality and fish communities in the selected study sites of Lake Victoria. Physico-chemical characteristics of water in selected sites were determined on-site while nutrients and heavy metals were determined in the laboratory using standard methods. Fish samples were collected using experimental multifilament gillnets with varying mesh sizes. Fish identification was done using external morphological characteristics and identification keys. Physico-chemical results in Thruston bay revealed rise in water column temperature and turbidity as compared to those measured by earlier studies on the lake. Dissolved oxygen (DO) ranged from $0.9 \mathrm{mg} \mathrm{L}^{-1}$ in $\mathrm{Yala}$ catchment to $11.56 \mathrm{mg} \mathrm{L}^{-1}$ in Thruston bay. Phosphorus (P) ranged from $9.78 \mu \mathrm{g} \mathrm{L}^{-1}$ to $120.67 \mu \mathrm{g} \mathrm{L}^{-1}$ in Thruston bay and in Yala catchment, it ranged from $185.2 \mu \mathrm{g} \mathrm{L}^{-1}$ to $1526.9 \mu \mathrm{g} \mathrm{L}^{-1}$. The nitrate-nitrogen loading in the Geita catchment ranged from 130 to $7465 \mathrm{~kg} \mathrm{~N}$ between the years 2006 and 2008. The results in the inshore sites show a potential for higher photosynthetic rates than in the offshore sites implying that there is more food for the fish in the inshore sites than in the offshore sites. Results further reveal that in Thruston bay there are 13 fish species and Haplochromines dominate the fish catch in terms of numbers. Heavy metals including mercury resulting from artisanal and commercial gold mining in the Geita study site were also detected in the discharges into the lake. This paper also presents measures for the sustainable management of the lake environment, its quality and fisheries.
\end{abstract}

Keywords: Fish, Geita wetlands, Lake Victoria, Nutrients, Thruston bay, Yala swamp, Water quality.

\section{INTRODUCTION}

Lake Victoria is the world's second largest freshwater lake by area and the largest in Africa with a surface area of $68,800 \mathrm{Km}^{2}$. It fills a shallow depression in the center of a great plateau at $1,134 \mathrm{~m}$ altitude located between the eastern and western rift valleys, holding $2,760 \mathrm{Km}^{3}$ of water at an average depth of 40 meters and reaching a maximum depth of 84 meters. This volume of water takes 100 years to be replaced by inflows. Situated on the equator, the temperature range in the lake is narrow and warm with a mean annual water mass temperature of $25^{\circ} \mathrm{C}$. The shoreline is about $3,500 \mathrm{Km}$ long and it is convoluted, enclosing innumerable small, shallow bays and inlets, many of which include swamps and wetlands that differ a great deal from one another and from the lake itself. The lake is a shared resource among the three riparian countries with Kenya having 6\%, Uganda $45 \%$ and Tanzania 49\% (Fig. 1). Rwanda and Burundi also have a share in the lake's catchment.

Over the past four decades or so, the lake has come under increasing and considerable pressure from a variety of inter-

\footnotetext{
*Address correspondence to this author at the Department of Zoology, Makerere University, P.O. Box 7062, Kampala, Uganda;

Tel: +256 414 531902; Fax: +256 414530134,

E-mail: fmuyodi@zoology.mak.ac.ug
}

linked human activities such as over-fishing, species introductions, industrial pollution, eutrophication, and sedimentation $[1,2]$. The lake provides various resources to its riparian communities, both renewable and non-renewable resources. Effective and efficient management of the resource base is essential for any nations' economic and social welfare and its environmental quality. Changes in population size, employment, settlement, consumption patterns, industrialization and resource utilization can affect the sustainability of the resources and environmental quality for better or for worse.

Contamination of environment with toxic heavy metals has become one of the major causes of concern for human kind. Heavy metals in surface water bodies, ground water and soils can be either from natural or anthropogenic sources. Currently, anthropogenic inputs of metals exceed natural inputs due to increased urbanization and industrialization. Industrial wastes, atmospheric deposition from crowded cities and other domestic wastes are among the major sources of heavy metals in the urban sewage [3].

In the 1980s, a shift in Lake Victoria's fauna became noticeable [4] although the origins of that shift began much earlier [5]. The bottom waters of the lake appeared to be a dead zone, devoid of oxygen and fish life. On the other hand, the lake was chockfull of algae, about five to ten times more 
than in the early 1960s [6]. That suggested massive eutrophication, an oxygen-depleted condition caused by high levels of nutrients that encourage the rapid growth of plankton. Nutrient inputs have increased at least two to three-folds since the turn of the century [7]. Concentrations of phosphorus have risen markedly in the deeper lake waters, and nitrogen around the edges [8] as nitrogen fixation rates have increased especially in inshore coastal waters [9]. In addition, massive blooms of algae have developed and become increasingly dominated by the potentially toxic blue-green species. Water transparency (as measured by the Secchi disc) has decreased from 5 meters in the early 1930s to 1 meter or less for most of the year in coastal waters now. Waterborne diseases have increased in frequency [2]. Water hyacinth, absent as late as 1989, has choked important waterways and landings although its abundance has declined in recent years in response to biological control [10]. These bays are generally shallow (normally 5-10 meters deep) in comparison to the more open waters. The shallower areas of the lake are infringed by extensive wetlands especially to the west and north of the lake. These bays are also sites of important fisheries, as they are breeding grounds of fishes [11].

Lake Victoria was the home of unique and diverse fish fauna $[12,13]$ that formed a special delicacy to the lakeshore communities. In the period 1950-1962 non-endemic fish species such as Oreochromis niloticus (L.), O. leucostictus (Trewavas), Tilapia zillii (Gervais) and Lates niloticus (L.) were introduced into Lake Victoria [13]. Factors such as introduction of alien fish species [14], increase in population, the use of wrong fishing gears and methods, destruction of the breeding and nursery grounds for the endemic fish species coupled with changes in the environmental conditions $[15,16])$ resulted in considerable changes in fish faunal composition. As Calamari et al. [17] noted, Lake Victoria pollution problem in the Kenyan waters of Lake Victoria was due to Kenya having a large catchment basin with six major rivers that carry pollutants into the Lake. This scenario has since persisted.

Fish distribution and abundance in different habitats is related to availability and abundance of food and substrate types. In addition fishes are not evenly distributed throughout a water body [11]. The physical habitat and the presence of other organisms and plants influence the distribution of fish, particularly those used for food and shelter. Many fish species or developmental stages of a species can only survive within a certain range of abiotic conditions such as temperature, oxygen, $\mathrm{pH}$, salinity and water currents [14]. Competition and predation may also limit some species to areas where their competitors and predators may not be able to tolerate a wide range of physiological conditions.

Two approaches are used to measure fish length: measurement of whole body and measurement of body parts. Whole body measurements are most commonly used in fishery investigations although partial measurements are useful in food studies or for fish that have been beheaded or have damaged tails or heads [18]. Three common whole-body measures of fish are total, fork, and standard lengths. Total length is defined as the length from the anterior-most part of the fish to the tip of the longest caudal fin rays.
It is more difficult and time consuming to weigh fish than to measure their length. Weighing fish under field condition presents special challenges. All fish carry with them a quantity of water on the body surface and in the buccal cavity. Small fish have a greater surface area for their volume or weight than do large fish. Because this quantity of water is variable among fish, it results in a loss of precision. To increase precision, water is allowed to drip from the fish or blot the fish before they are weighed [18]. Parker [19] reported that blotting of fish before they were weighed improved the accuracy. Damp chamois or cloth can be used to blot much of the surface moisture from fish without causing damage [18].

The production process results in the creation of tissue by individuals and population. Although production can be expressed as calories or weight of carbon, protein, or dried tissue, all these measures are normally based on a measurement of wet or live weight. From the fisheries perspective, total weight or weight per unit of area is the statistic normally reported for harvest or standing crop. Length and weight data can also be used to calculate condition factors or indices of fish well-being [18].

A number of studies have been conducted in the Lake Victoria basin but none of them linked the levels of environmental quality to fish composition, abundance and distribution. Many of the studies either looked at fish species composition and distribution per se, or water quality per se, while others studied heavy metal concentrations in fish and other organisms per se; without linking these parameters to environmental quality $[7-9,12,13,15,16]$. The present study differs from them as it examines the link between environmental quality and fish composition, abundance and distribution in the selected sites of Lake Victoria. The specific objectives of the study where therefore to: (i) establish the levels of environmental quality parameters (physicochemical and biological), (ii) determine the fish species composition, abundance and distribution, and (iii) establish the effect of water quality on socio-economic well being of the riparian communities of Lake Victoria. This paper hence presents findings on the link between environmental quality and fish communities, some aspects of socio-economic parameters as regards to declining fish catch versus environmental quality and suggests measures for restoration and sustainable management of the lake ecosystem.

\section{MATERIAL AND METHODOLOGY}

\subsection{Study Area}

The study was conducted in Uganda, Kenya and Tanzania catchments of Lake Victoria. The study sites for this project are (Thruston bay) on the Ugandan side and Yala catchment on the Kenyan side and Geita on the Tanzanian part of the lake.

Thruston Bay, with an area of approximately 1650 hectares, is located in the northeastern region of Napoleon Gulf, Lake Victoria. Thruston Bay has an average depth of $5 \mathrm{~m}$ and a maximum depth of $11 \mathrm{~m}$. In contrast to other nearby bays, such as, Fielding and Hannington, Thruston Bay has a large littoral wetland region dominated by the macrophytes Cyperus papyrus (papyrus), Phragmites mauritianus (reeds), Ty- 
pha domingensis (cattails), Vossia cuspidata (hippo grass) and Eichhornia crassipes (water hyacinth). Three distinct shoreline types can be distinguished. These include a papyrus-dominated sub-bay (Kikafunda Bay), a forested eastern shoreline and a rocky Phragmites-Vossia stretch to the west. Between 1996 and 1998 about 800ha of Thruston Bay was covered with thick mats of water hyacinth. However, following the impact of biological control weevils and other environmental factors, including nutrient depletion and changes in water levels, the compacted mats collapsed and sank to the bottom of the bay. Between 1999 and 2000, dissolved oxygen (DO) levels were between $2.5-5.5 \mathrm{mg} \mathrm{L}^{-1}$ [20]. In December 2000 , surface water quality parameters in the shallow $(<4 \mathrm{~m})$ littoral wetland habitats of the bay were: DO, 4.9 $\mathrm{mg} \mathrm{L}^{-1}$; conductivity, $110.7 \mu \mathrm{s} \mathrm{cm}^{-1}$; total phosphorus, 30.6 $\mu \mathrm{g} \mathrm{L}^{-1}$; ammonia, $0.5 \mu \mathrm{g} \mathrm{L}^{-1}$; and chlorophyll- $a$, $64.3 \mu \mathrm{g} \mathrm{L}^{-1}$ [20].

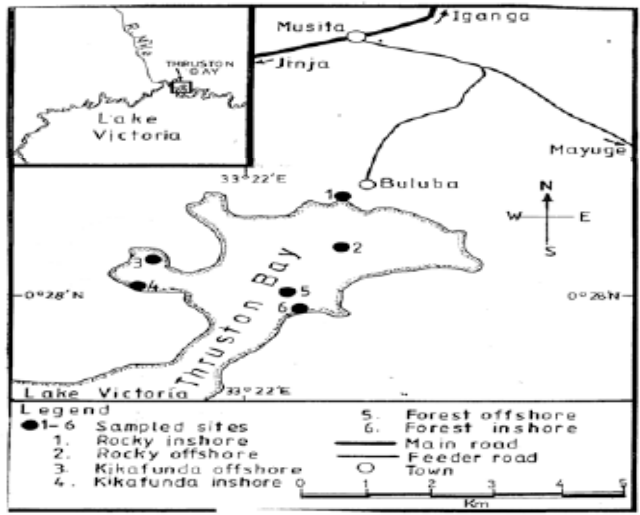

1a)

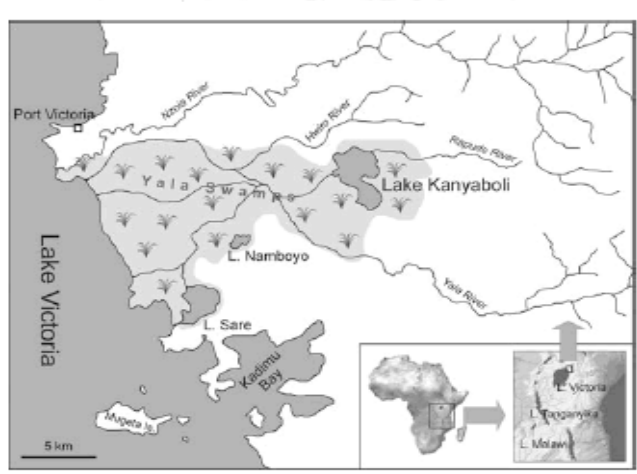

1b)

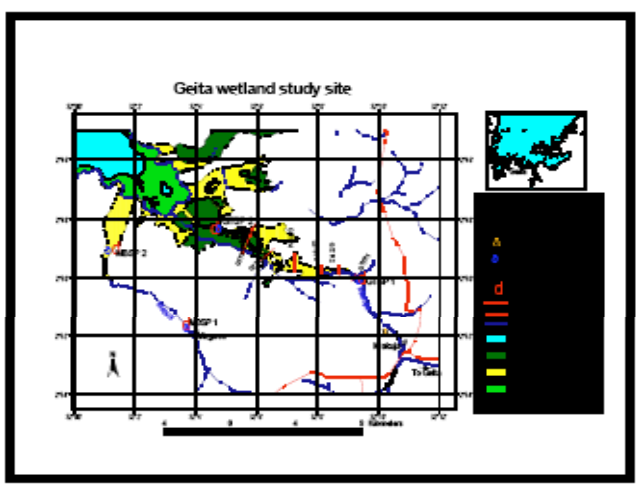

1c)

Fig. (1). Location map of Lake Victoria, showing study sites: (1a) Thruston Bay, Uganda, (1b) Yala swamp catchment, Kenya, (1c) Geita catchment, Tanzania.
In the present study each of these three Thruston Bay habitats (Kikafunda, a forested eastern shoreline and a rocky stretch) had two sampling spots (the inshore and offshore) where sampling for fish and water quality parameters was done. The GPS (Garmin GPS 12 Channel) reference for Kikafunda Inshore site was $00^{0} 28.076^{\prime} \mathrm{N}$ and $033^{\circ} 21.323^{\prime} \mathrm{E}$ while the offshore site was $00^{\circ} 28.076^{\prime} \mathrm{N}$ and $033^{\circ} 21.323^{\prime} \mathrm{E}$. For the Forested eastern shoreline study site, the GPS points for the Inshore site were $00^{\circ} 27.819^{\prime} \mathrm{N}$ and $033^{\circ} 22.678^{\prime} \mathrm{E}$ while for the offshore site were $00^{0} 27.885^{\prime} \mathrm{N}$ and $033^{0} 22.841^{\prime} \mathrm{E}$. The reference points for the Rocky Inshore site were $00^{\circ} 29.421^{\prime} \mathrm{N}$ and $033^{\circ} 22.902^{\prime} \mathrm{E}$ while that for the Rocky Offshore were $00^{\circ} 29.176^{\prime} \mathrm{N}$ and $033^{0} 23.034^{\prime} \mathrm{E}$. Fig. (1) presents the location map of Lake Victoria, showing the study catchments.

River Yala catchment, in the upstream swamp which has been least interfered with before, now houses Dominion Farms which is undertaking intensive agricultural activities with devastating impacts on the swamp, related lakes downstream and fishing activities at the shores of Lake Victoria at Usenge beach. The Yala swamp is Kenya's largest freshwater wetland, covering approximately $175 \mathrm{~km}^{2}$ along the northern shore of Lake Victoria, Kenya. It is bordered in the North by the Nzoia River and in the South by the Yala River. Three main lakes (Kanyaboli, Namboyo and Sare), of which Lake Kanyaboli is the largest and farthest from Lake Victoria, are found within the Yala swamps. On the Kenyan side the immediate catchments around Kisumu town are also considered because of the local industries like the Molasses Plant, and the River Kisat with effluents flowing into the lake.

Geita study site is polluted by mining activities in the upstream and agricultural practices in the area. There is smallscale artisanal and large-scale gold mining in the upstream. The washings and use of mercury drains through a small river nearby which immediately empties into Lake Victoria next to a fish landing beach. It is also at this point where there is a water intake for domestic use in a local market and Geita town. This is likely to have resulted in the pollution of wetland with this heavy metal. Agricultural activities have resulted in the widespread conversion of this wetland into rice fields, and the accidental release of agrochemicals.

\subsection{Water Sampling and Laboratory Analysis}

Field sampling in the three selected sites started in January and March 2008 in Uganda and Kenya and 2006 in Tanzania respectively. In-situ water measurements of temperature, dissolved oxygen, conductivity, $\mathrm{pH}$ and transparency (Secchi depth) are determined in the field for each station. Water samples were collected for analysis of nutrients (P, N and Si components) and algal biomass (chlorophyll-a) in the laboratory. Water samples were analyzed for dissolved nutrients which included nitrate nitrogen $\left(\mathrm{NO}_{3}-\mathrm{N}\right)$; phosphate phosphorus $\left(\mathrm{PO}_{4}-\mathrm{P}\right)$; total nitrogen $(\mathrm{TN})$; total phosphorus (TP), chlorophyll-a (Chlo-a) and Biological Oxygen Demand (BOD). Water samples were immediately filtered using cellulose acetate membrane filters (pore size $0.45 \mu \mathrm{m}$ ) and laboratory analysis was done immediately after delivery. Analysis was done using spectrophotometric methods as outlined in [21] and [22]. In the River Yala swamps, sampling points 
are located at the mouths of River Yala (three spots at Osieko River, Osieko beach and Goye Bridge) and effluent discharge points from the Molasses Plant and River Kisat (three spots at Kudho, Obunga and Kisat Bridge) just in the outskirts of Kisumu city. In the Geita catchment, heavy metals which included mercury $(\mathrm{Hg})$, nickel $(\mathrm{Ni})$ and copper $(\mathrm{Cu})$ were tested using a Perkin Elmer Flame Atomic Absorption Spectrophotometer based on standards methods [22].

\subsection{Fish Sampling in Thruston Bay}

Monthly samplings were conducted for a period of six months from January 2008 using experimental multifilament gillnets of varying mesh size from 1 to $8 \mathrm{inch}$. At each of the study sites, two fleets of gillnets were set one inshore and another offshore (about $100 \mathrm{~m}$ from shoreline), and were parallel to the shoreline. Gillnets were set in the evening between $5.00 \mathrm{pm}$ and $7.00 \mathrm{pm}$, left overnight, and retrieved the following morning between 7.00am and $9.00 \mathrm{am}$. The retrieved fish specimens were sorted, weighed and size structure determined, and identified using external morphological characteristics and identification keys [12, 23, 24]. Fish of a given species were counted and total numbers of each species caught per study site recorded in a catch composition data sheet. In the present study, fish sampling and biometrics was not done in the other two sites (Geita and Yala catchment) as results from Thruston bay study would be applicable to those sites and the entire wetland ecosystems of the lake. Various previous studies had also looked at fish and fish biometrics in these study sites [20, 25, 26].

\subsection{Fish Length Measurements}

The Total length (TL) of fish specimens at each study site were measured to the nearest millimeter using a measuring board. The anterior most extremity of the fish (mouth closed) was put against a stop at the beginning of the measuring board to the end of the tail fin [12]. The specimens whose body parts had been eaten away were not considered for this analysis, and thus regarded as waste samples.

\subsection{Fish Weight Measurements}

The wet weights of individuals or groups of fish species at each fishing ground were measured with the aid of a threebeam balance model DIAL-O- GRAM to the nearest gram. Before fish was weighed, a damp cloth was used to blot much of the surface moisture from fish without causing damage. The total weight of each fish species was measured separately in a polyethylene bag using a $100-\mathrm{kg}$ spring balance. The total weight of each fish taxa was recorded in catch composition data sheet.

\subsection{Fish Species Composition and Abundance}

Fish species composition was determined for each study site in the Thruston bay as the number of different species recovered. Fish species abundance at the fishing grounds was estimated in terms of numbers and biomass. Data collected was analyzed using SPSS statistical package (Version 16) and descriptive statistics. Fish data was related to environmental data to determine if there was any relationship between the two.

\subsection{Socio-Economic Survey}

The survey was undertaken among the community members including boat owners and crew members who actually go out fishing. Questionnaires were administered to 30 respondents within areas from which water samples were taken and the related beaches. The exercise which went on parallel to water sampling was meant to capture opinions and perspectives of the fisher folk on water quality, fish abundance, and their well being.

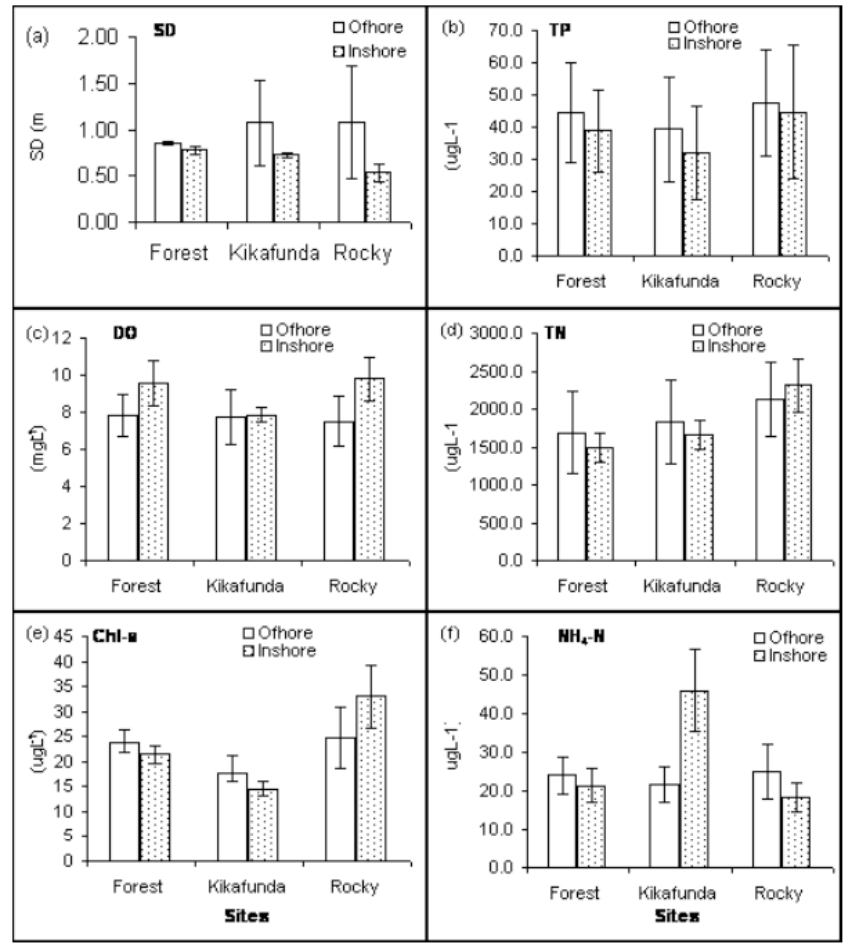

Fig. (2). Mean values of water quality parameters in the study sites of Thruston bay (a) Secchi depths (SD) (b) Total phosphorus (TP) (c) Dissolved oxygen (DO) (d) Total nitrogen (TN) (e) Algal biomass (Chlo-a) and (f) Ammonium nitrogen $\left(\mathrm{NH}_{4}-\mathrm{N}\right)$. (Note: $u$ in the figure represents symbol $\mu)$.

\section{RESULTS AND DISCUSSION}

\subsection{Environmental Quality Parameters}

Water quality parameters in the sampled sites of Lake Victoria (Thruston Bay) are presented in Fig. (2). The parameters varied from site to site. Water temperature is found to have increased and transparency values decreased compared to those measured by earlier studies in Lake Victoria for both inshore and offshore sites [11,27]. This may be as a result of removal of vegetation at the inshore sites. Nitrite concentrations were relatively higher in the inshore sites of rocky and papyruses as these are the building chains for the food of fish algae. Dissolved oxygen values are higher in the rocky and papyrus sites due to mixing as these sites have macrophytes and stones on which water mixes as it gets in contact with them.

Primary data on heavy metals in water and fish samples were not collected in the Thruston bay in the present study. Various previous studies had looked at this $[20,25,26]$. Muwanga and Barifaijo [25] recorded heavy metal concen- 
trations in water and fish samples from the Napolean gulf, where Thruston bay is also located. In water samples, $\mathrm{Cu}$ ranged from 0.01 to $0.02 \mathrm{mg} \mathrm{L}^{-1} ; \mathrm{Pb}$ ranged from 0.01 to $0.26 \mathrm{mg} \mathrm{L}^{-1} ; \mathrm{Zn}$ ranged from 0.00 to $0.03 \mathrm{mg} \mathrm{L}^{-1}$; Cd ranged from 0.001 to $0.019 \mathrm{mg} \mathrm{L}^{-1}$; $\mathrm{Cr}$ ranged from 0.01 to $0.02 \mathrm{mg}$ $\mathrm{L}^{-1}$; Ni ranged from 0.01 to $0.07 \mathrm{mg} \mathrm{L}^{-1}$; Co ranged from 0.01 to $0.16 \mathrm{mg} \mathrm{L}^{-1}$ and $\mathrm{Mn}$ ranged from 0.01 to $0.35 \mathrm{mg} \mathrm{L}^{-1}$. In fish samples, the average concentrations of total mercury ( $\mathrm{THg}$ ) were found to be between 24.2 to $35.4 \mathrm{ng} \mathrm{g}^{-1}$ wet weight [25] in Protopterus aethiopicus (Lung fish) indicating that mercury concentrations in fish were below international limits (EC standard: 0.5 to $1 \mathrm{ppm}$ or 500 to $1000 \mathrm{ng} \mathrm{g}^{-1}$ wet weight).

Campbell et al. [20] recorded total $\mathrm{Hg}$ concentrations in fish from Thruston bay, Napolean gulf, as follows: Lates niloticus (Nile perch) (range 22.9 to $150.2 \mathrm{ng} \mathrm{g}^{-1}$ wet weight); Oreochromis niloticus (Nile tilapia) (range 1.7 to25.7 $\mathrm{ng} \mathrm{g}^{-1}$ wet weight); Protopterus aethiopicus (Lung fish) (27.2 $\mathrm{ng} \mathrm{g}^{-1}$ wet weight); Clarias gariepinus (29.0 $\mathrm{ng} \mathrm{g}^{-}$ ${ }^{1}$ wet weight); Haplochromine spp. (55.5 $\mathrm{ng} \mathrm{g}^{-1}$ wet weight); Oreochromis leucostiicus (0.6 to $2.2 \mathrm{ng} \mathrm{g}^{-1}$ wet weight); Tilapia zilli (3.9 $\mathrm{ng} \mathrm{g}^{-1}$ wet weight). The recorded concentrations were lower than in the same fish species from elsewhere in Napolean gulf and were in the middle of the range of total $\mathrm{Hg}$ concentrations across Lake Victoria. The lower concentrations of mercury in fish were attributed to the storage capacity, high oxygen concentrations and high organic matter content of wetlands surrounding Thruston bay.

Table 1 presents the water quality parameters from sampling stations in the three key study areas of R. Yala mouths, River Kisat and Molasses plant discharge point. It is seen from Table 1 that discharge from the Molasses plant is comparable to the one from River Kisat. The levels of conductivity, turbidity and hardness were very high. The same was true for the other parameters including alkalinity, Biological Oxygen Demand (BOD), levels of ammonia, soluble reactive phosphorus (SRP), Total Nitrogen (TN) and Total Phosphorus (TP). Because of these high levels pollutants in the discharge, it is seen that they are the worst polluters of the Yala catchment and are the major threats to the aquatic and human lives in the adjacent beaches. The data also show that the discharge from River Yala is low in terms of the chemicals and heavy metals, suggesting that it poses insignificant threat so far to the Lake as compared to River Kisat and the Molasses plant.

A Parallel study by Ogoyi et al [26] analyzed heavy metals in water and sediment samples from the Yala catchment. In water samples, $\mathrm{Zn}$ ranged from 0.03 to $0.47 \mathrm{mg} \mathrm{L}^{-1} ; \mathrm{Pb}$ ranged from 0.00 to $1.622 \mathrm{mg} \mathrm{L}^{-1}$; $\mathrm{Cd}$ ranged from 0.00 to $0.03 \mathrm{mg} \mathrm{L}^{-1}$; $\mathrm{Cr}$ ranged from 0.00 to $0.30 \mathrm{mg} \mathrm{L}^{-1}$ while $\mathrm{Hg}$ ranged from 0.000 to $0.001 \mathrm{mg} \mathrm{L}^{-1}$. These values are in agreement with those that were recorded in the present study for the Geita catchment. They were however higher than those reported in literature for the Napolean gulf where Thruston bay is located. This is attributed to the higher pollution loading in the Yala and Geita catchments (categorized as urban-influenced catchments) as compared to the Thruston bay (a rural-influenced catchment).

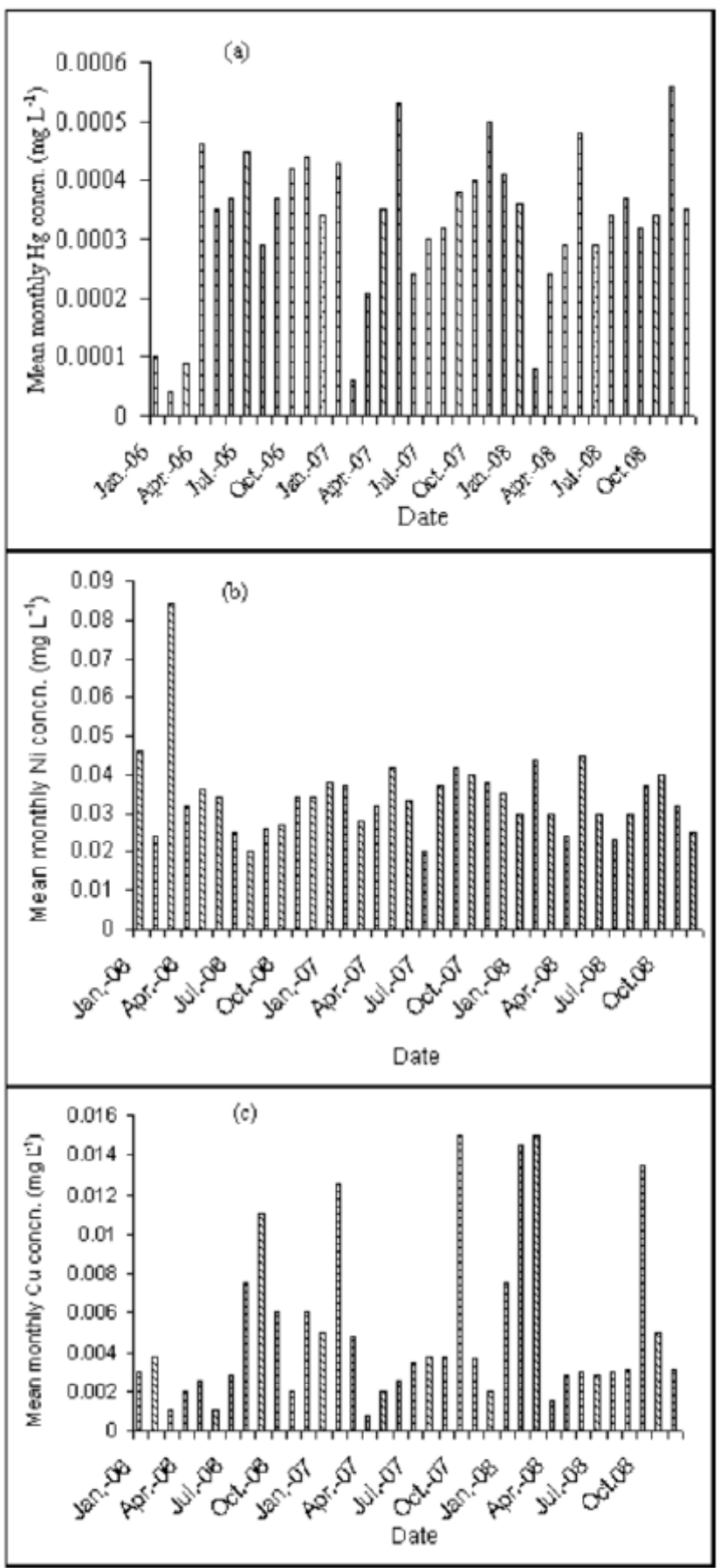

Fig. (3). Heavy metals in water samples from Geita catchment for 2006 to 2008 (a) $\mathrm{Hg}$, (b) $\mathrm{Ni}$ and (c) $\mathrm{Cu}$.

The mean values of nutrient concentrations and loadings are presented in Table 2 while Fig. (3) presents concentration of heavy metals for the Geita catchment study area. The values for the nitrate, nitrite and ammonium loadings as presented (Table 2) are very high as compared to those in the Thruston bay and Yala catchments. The high nutrient loadings from the Geita catchment into the lake reflected in the general decline in water quality. Increased algal blooms, depletions of dissolved oxygen, frequent large-scale mortalities of fish, and changes in other biotic species composition, proliferation of the water hyacinth and increasing human 
Table 1. Water Quality Parameters from the Sampling Stations in the Three Key Study Areas of the River Yala Catchment (Kenya)

\begin{tabular}{|c|c|c|c|}
\hline Stations Parameters & River Yala & Molasses Plant Effluent Discharge Point & Kisat \\
\hline Temperature $\left({ }^{\circ} \mathrm{C}\right)$ & 26.5 & 31.9 & 29.0 \\
\hline $\mathrm{pH}$ & 7.9 & 8.2 & 7.3 \\
\hline Conductivity $\left(\mu \mathrm{Scm}^{-1}\right)$ & 115.5 & 509.0 & 452.0 \\
\hline Turbidity (NTU) & 48.2 & 201.0 & 379.6 \\
\hline Dissolved Oxygen $\left(\mathrm{mg} \mathrm{L}^{-1}\right)$ & 4.9 & 0.9 & 1.1 \\
\hline Hardness (mg L $\left.{ }^{-1}\right)$ & 32.0 & 114.5 & 103.7 \\
\hline $\begin{array}{l}\text { Alkalinity }\left\{\mathrm{CaCO}_{3}\right\} \\
\left(\mu \mathrm{g} \mathrm{L}^{-1}\right)\end{array}$ & 46.3 & 327.0 & 198.3 \\
\hline BOD $\left(\mathrm{mg} \mathrm{L}^{-1}\right)$ & 3.6 & 67.0 & 40.5 \\
\hline Ammonia $\left(\mu \mathrm{g} \mathrm{L}^{-1}\right)$ & 98.9 & 598.7 & 1149.1 \\
\hline SR-Phosphorus $\left(\mu \mathrm{g} \mathrm{L}^{-1}\right)$ & 23.0 & 580.0 & 618.5 \\
\hline Nitrates $\left(\mu \mathrm{g} \mathrm{L}^{-1}\right)$ & 34.5 & 7.6 & 55.9 \\
\hline Silicates $\left(\mu \mathrm{g} \mathrm{L}^{-1}\right)$ & 5.0 & 6.4 & 13.9 \\
\hline Total Nitrogen $\left(\mu \mathrm{g} \mathrm{L}^{-1}\right)$ & 300.3 & 395.5 & 357.6 \\
\hline $\begin{array}{l}\text { Total Phosphorus } \\
\left(\mu \mathrm{g} \mathrm{L}^{-1}\right)\end{array}$ & 185.2 & 1526.9 & 810.9 \\
\hline
\end{tabular}

Table 2. Mean Nutrient Loadings at Sampling Site in the Geita Catchment (Tanzania) from 2006 to 2008.

\begin{tabular}{|c|c|c|c|}
\hline \multirow{2}{*}{ Nutrient } & \multicolumn{3}{|c|}{ Year } \\
\cline { 2 - 4 } & $\mathbf{2 0 0 6}$ & $\mathbf{2 0 0 7}$ & $\mathbf{2 0 0 8}$ \\
\hline \hline $\begin{array}{c}\mathrm{NO}_{3}-\mathrm{N} \\
\mathrm{Conc}\left(\mathrm{mg} \mathrm{L}^{-1}\right)\end{array}$ & $1.4125 \pm 0.8$ & $1.3 \pm 0.8$ & $1.2 \pm 0.6$ \\
\hline $\begin{array}{c}\mathrm{NO}_{3}-\mathrm{N} \\
\mathrm{Load}(\mathrm{kg} \mathrm{N})\end{array}$ & $2238 \pm 2390$ & $2084.6 \pm 2260$ & $1961.3 \pm 1845.8$ \\
\hline $\begin{array}{c}\mathrm{NH}_{4}-\mathrm{N} \\
\text { Conc }\left(\mathrm{mg} \mathrm{L}^{-1}\right)\end{array}$ & $2.0 \pm 1.4$ & $1.5 \pm 0.7$ & $1.7 \pm 1.0$ \\
\hline $\begin{array}{c}\mathrm{NH}-\mathrm{N} \\
\text { Load }(\mathrm{kg} \mathrm{N})\end{array}$ & $2672.6 \pm 2841$ & & $2465.5 \pm 2508.2$ \\
\hline
\end{tabular}

health risks also manifest the ecological degradation of the lake.

Due to its many health threats, mercury $(\mathrm{Hg})$ is regulated in foods, pesticides and industry. But some gold mining plants in the Lake Victoria basin discharge mercury into water at levels hundreds of times greater than deemed safe for wildlife and up to 25 times greater than deemed safe for humans. Mercury levels are not regulated at all during artisanal gold mining. The mercury standards were developed to ensure wildlife safety. But mercury also poses a risk to humans. Mercury also occurs naturally in the environment, but is transformed into a more dangerous form by bacteria and plants in the water. This new form, called methylmercury, builds up in fish. Consuming contaminated fish can cause heart, kidney, and lung damage. Pregnant women are ad- vised to limit their consumption of mercury contaminated fish, since mercury can damage the brain of their fetus. In the present study, $\mathrm{Hg}$ levels ranged from $<0.0001$ to about $0.0005 \mathrm{mg} \mathrm{L}^{-1}$.

Nickel (Ni) is reported to be one of the toxic heavy metals to aquatic life and humans once these are exposed to higher levels above the acceptable minimum. It leads to high prevalence of fish diseases and abnormalities in organs, particularly in kidneys and liver [28]. In the present study, $\mathrm{Ni}$ concentrations were observed to be high compared to those of $\mathrm{Hg}$ and $\mathrm{Cu}$ recorded. It ranged from $0.02 \mathrm{mg} \mathrm{L}^{-1}$ to about $0.085 \mathrm{mg} \mathrm{L}^{-1}$.

Copper $(\mathrm{Cu})$ is a metal found in natural deposits as ores containing other elements. It is widely used in household 
Table 3. Composition, Distribution and Relative Abundance (Numbers) of Fish Taxa Recorded from Thruston Bay

\begin{tabular}{|c|c|c|c|c|}
\hline \multirow[b]{2}{*}{ Fish Species } & \multicolumn{4}{|c|}{ Sampling Site } \\
\hline & Forest (Iguluibi) $n=6$ & $\begin{array}{c}\text { Kikafunda } \\
\text { (Papyrus) n=6 }\end{array}$ & $\begin{array}{c}\text { Rocky } \\
\text { (Buluba) n=6 }\end{array}$ & Total \\
\hline Astatoreochromis alluaudi & 0 & 135 & 0 & 135 \\
\hline Brycinus jacksonii (Boulenger) & 4 & 0 & 7 & 11 \\
\hline Brycinus sadleri & 8 & 122 & 14 & 144 \\
\hline Clarias gariepinus (Burchell) & 0 & 3 & 3 & 6 \\
\hline Haplochromines & 48 & 778 & 54 & 880 \\
\hline Lates niloticus & 167 & 79 & 421 & 667 \\
\hline Mormyrus kannume (Forsskal) & 1 & 0 & 0 & 1 \\
\hline Oreochromis leucostictus & 8 & 7 & 22 & 37 \\
\hline Oreochromis niloticus & 25 & 13 & 116 & 154 \\
\hline Protopterus aethiopicus (Heckel) & 1 & 13 & 0 & 14 \\
\hline Synodontis afrofischeri & 5 & 0 & 397 & 402 \\
\hline Synodontis victoriae & 0 & 1 & 9 & 10 \\
\hline Tilapia zillii & 2 & 8 & 13 & 23 \\
\hline Total & 269 & 1024 & 1056 & 2349 \\
\hline
\end{tabular}

$\mathrm{n}=$ Number of sampling occasions.

plumbing materials. Short- and long-term effects: Copper is an essential nutrient, required by the body in very small amounts. The drinking water standards for copper are set at $1.3 \mathrm{mg} \mathrm{L}^{-1}$ by the Environmental Protection Agency (EPA) of the United States, for example. However, copper is known to potentially cause the following health effects when people are exposed to it at levels above this action level. Short periods of exposure can cause gastrointestinal disturbance, including nausea and vomiting. Use of water that exceeds the $1.3 \mathrm{mg} \mathrm{L}^{-1}$ over many years could cause liver or kidney damage. People with Wilson's disease may be more sensitive than others to the effect of copper contamination. In the present study, $\mathrm{Cu}$ levels ranged from $<0.001$ to about $0.014 \mathrm{mg}$ $\mathrm{L}^{-1}$.

\subsection{Fish Biometric Characteristics}

\subsubsection{Fish Composition, Distribution and Abundance in Thruston Bay}

A total of 13 fish species were recorded from the sampled sites (Table 3). Haplochromines $(37.4 \%)$ were numerically the most dominant followed by the Nile perch $(28.4 \%)$. In Thruston bay, the Rocky site had the highest number of fishes (1056), followed by Papyrus (Kikafunda) site with 1024 and Forest site recorded the lowest number of fish (269). Distribution among sites varied with site. Brycinus sadleri (Boulenger), Haplochromines, Lates niloticus, Oreochromis leucostictus, Oreochromis niloticus and Tilapia zillii were recorded from all sites. Nile perch was numerically the most dominant species in all the sites except in Kikafunda
(Papyrus) were haplochromine cichlids dominated the catch. Synodontis afrofischeri (Hilgendorf) and Synodontis victoriae (Boulenger) were most dominant in rocky habitat $(\mathrm{Bu}-$ luba).

Table 4 presents percentages of fish species composition in Thruston and the nearby bays of Murchison, Fielding and Hannington. Murchison, Fielding and Hannington bays are influenced by inputs from catchments of urban, semi-urban and rural land use origin respectively. In contrast to these nearby bays, Thruston bay has a large littoral wetland region dominated by the macrophytes Cyperus papyrus (papyrus), Phragmites mauritianus (reeds), Typha domingensis (cattails), Vossia cuspidata (hippo grass) and Eichhornia crassipes (water hyacinth) and is totally characterized by a rural land use practices [29]. The results suggest that Thruston bay has the highest number of fish species (13) compared to the other bays. This is attributed to the diverse ecological habitats including the wetlands around this bay. The dominant fish species in the bays were Haplochromines, Lates niloticus and Synodontis afrofischeri (in Thruston); Protopterus aethiopicus, Oreochromis niloticus and Brycinus sadleri (in Murchison); Oreochromis niloticus, Protopterus aethiopicus and Lates niloticus (in Fielding) and Protopterus aethiopicus, Haplochromines and Lates niloticus (in Hannington bay). The species that was common in all the bays in very significant percentages was Lates niloticus.

Table 5 presents mean total length (TL) and weight (Wt) for fish from Thruston Bay. Whole body measurements, such as, total length are most commonly used in fishery investiga- 
Table 4. Percentage Fish Species Composition in Thruston Bay in Relation to Other Bays in Lake Victoria

\begin{tabular}{|c|c|c|c|c|}
\hline Fish Species & \multicolumn{4}{|c|}{ Composition as Percent of Total Sampled (\%) } \\
\hline Brycinus jacksonii & 0.5 & 0.0 & 1.0 & 0.0 \\
\hline Brycinus sadleri & 6.1 & 13.0 & 2.0 & 8.0 \\
\hline Haplochromines & 31.8 & 11.0 & 4.0 & 26.0 \\
\hline Lates niloticus & 28.4 & 11.0 & 17.0 & 12.0 \\
\hline Mormyrus kannume & 0.1 & 0.0 & 1.0 & 0.0 \\
\hline Oreochromis leucostictus & 1.8 & 2.0 & 4.0 & 0.0 \\
\hline Synodontis afrofischeri & 17.1 & 2.0 & 0.0 & 0.0 \\
\hline Synodontis victoriae & 0.4 & 0.0 & 0.0 & 0.0 \\
\hline Tilapia zillii & 1.0 & 0.0 & 5.0 & 2.0 \\
\hline Oreochromis variabilis & 0.0 & 2.0 & 1.0 & 0.0 \\
\hline
\end{tabular}

${ }^{a}$ Adopted from Sekiranda et al. [29].

Table 5. Mean Total Length (TL), Weight (Wt) for Fish From Thruston Bay. The Letter N of 1 is One Sample, Not One Organism.

\begin{tabular}{|c|c|c|c|c|c|c|}
\hline $\begin{array}{c}\text { Characteristic } \\
\text { Study Year }\end{array}$ & 2010 & Campbell & 2010 & Campbell & 2010 & Campbell \\
\hline Lates niloticus & 4 & 9 & 16.2 & $44.7 \pm 24.2$ & $533 \pm 497$ & $2029 \pm 2524$ \\
\hline Protopterus aethiopicus & 4 & 1 & 52.1 & 72 & $1770 \pm 933$ & 450 \\
\hline Haplochromines & 4 & 1 & 11.7 & 16 & $207 \pm 258$ & 62 \\
\hline Oreochromis leucostictus & 4 & 4 & 11.5 & $17.1 \pm 0.8$ & $122 \pm 110$ & $85.8 \pm 12.1$ \\
\hline Oreochromis niloticus & 4 & 8 & 12.8 & $23.5 \pm 9.8$ & $178 \pm 176$ & $421.8 \pm 607.9$ \\
\hline
\end{tabular}

\pm Standard deviation

tions. Total length is defined as the length from the anteriormost part of the fish to the tip of the longest caudal fin rays. In fisheries, length is used to define the legal size for harvest. In addition, length is often better than age as an indicator of maturity. Total length (TL) in the present study was significantly lower than that reported in literature from earlier studies [20]. This implies that more fish in the study area is becoming shorter than previously recorded or the majority of the fish sampled were in the immature range. This may either be attributed to deteriorating habitat conditions making the fish become stunted or increased fishing pressure has eliminated most of the mature fish. The weights indicated in the present study suggest a general decrease in weight of most fish species except for Protopterus aethiopicus and Haplochromines.

\subsubsection{Relationship between Water Quality and Total Fish Catch}

There was a direct relationship between the number of fish caught and water transparency as determined by the Secchi depth. Fig. (4) presents variation of fish catch against secchi depths along sites in Thruston bay. It appeared that (Fig. 4) the more turbid the water was, the more was the fish 
Table 6. Fish Catch Numbers in Relation to Dissolved Oxygen (DO) in Thruston Bay, Lake Victoria.

\begin{tabular}{|c|c|c|c|c|c|c|c|c|}
\hline Sampling & \multicolumn{2}{|c|}{ Sampling Occasion 1 } & \multicolumn{2}{c|}{ Sampling Occasion 2 } & \multicolumn{2}{c|}{ Sampling Occasion 3 } & Sampling Occasion 4 \\
\hline \hline Site & Fish Catch & $\begin{array}{c}\text { DO } \\
\left(\mathrm{mg} \mathrm{L}^{-1}\right)\end{array}$ & Fish Catch & $\begin{array}{c}\text { DO } \\
\left(\mathrm{mg} \mathrm{L}^{-1}\right)\end{array}$ & Fish Catch & $\begin{array}{c}\text { DO } \\
\left(\mathrm{mg} \mathrm{L}^{-1}\right)\end{array}$ & $\begin{array}{c}\text { Fish Catch } \\
\left(\mathrm{mg} \mathrm{L}^{-1}\right)\end{array}$ \\
\hline Rocky & 193 & 9.07 & 331 & 10.68 & 172 & 6.62 & 360 & 10.20 \\
\hline Kikafunda & 100 & 8.74 & 301 & 8.74 & 83 & 6.64 & 230 & 8.74 \\
\hline Forest & 74 & 7.68 & 87 & 9.95 & 19 & 6.17 & 89 & 9.95 \\
\hline
\end{tabular}
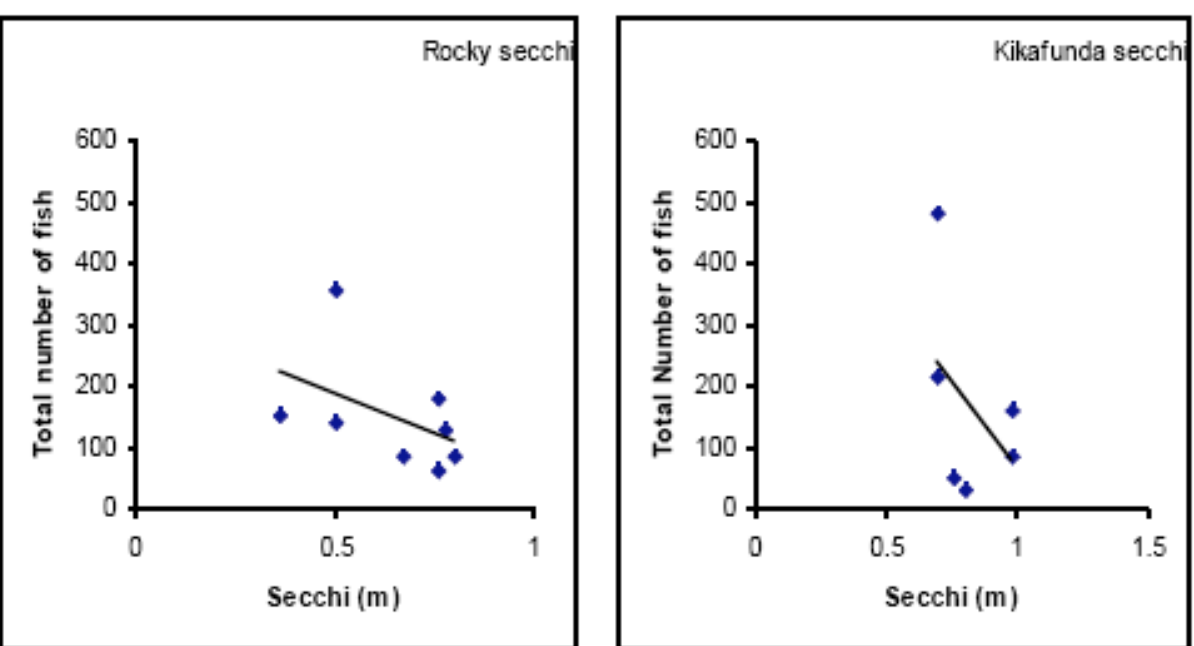

Fig. (4). Plot of Variation of fish catch against Secchi depths along the sites in Thruston bay.
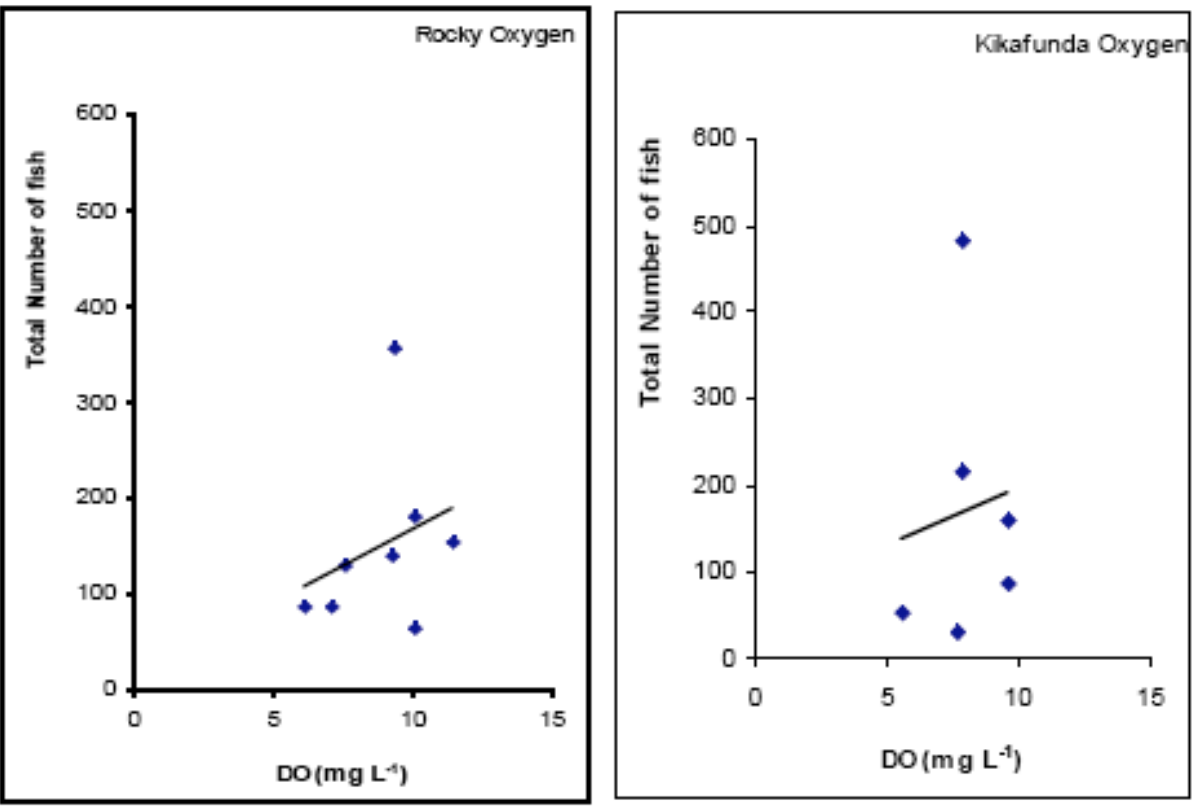

Fig. (5). Plot of variation of fish catch and Dissolved Oxygen (DO) levels at the sampling sites in Thruston bay.

catch. Likewise, the less turbid the water was, the less the fish abundance and henceforth the less the fish catch. It was also observed that dissolved oxygen concentration showed a direct relationship with fish abundance and hence fish catch (Fig. 5). The higher the concentration, the higher was the abundance and catch in the sites.
The results also showed that among the three sites in Thruston bay, the rocky site had the highest dissolved oxygen concentration (Table 6). There was a relationship between the numbers of fish caught and the dissolved oxygen levels at this site. Other water quality parameters also showed some relationship with abundance and fish catch, 
Table 7. Main Occupation for Income Generation in the Beaches in the Yala Catchment Study Areas

\begin{tabular}{|l|c|c|}
\hline Activity & $\begin{array}{c}\text { Number of People } \\
\text { Involved Per Year }\end{array}$ & $\begin{array}{c}\text { Average No. of } \\
\text { Months }\end{array}$ \\
\hline \hline Owning/Renting boats & 12 & 9 \\
\hline $\begin{array}{l}\text { Fishing Employment } \\
\text { (Crews) }\end{array}$ & 7 & 12 \\
\hline Fish trading/Processing & 8 & 12 \\
\hline Net Making \& Repairing & 1 & 4 \\
\hline $\begin{array}{l}\text { Boat Building \& Repair- } \\
\text { ing }\end{array}$ & - & - \\
\hline Farming \& Livestock & 13 & 12 \\
\hline Non- fishing Activities & 8 & 12 \\
\hline
\end{tabular}

although this was not as strong and direct as that expressed by water transparency, chlorophyll-a and dissolved oxygen concentrations.

The increase in fish catches with increase in dissolved oxygen levels in the bay was in agreement with other findings elsewhere [30]. Oxygen is also essential for the live foods for the fish which includes algae, rotifers and cladocerans. Results suggest that more dissolved oxygen (DO) favored more fish abundance and hence more catches along the sites. From Table 6, the Rocky site had the highest values ranging from 6.62 to $10.68 \mathrm{mg} \mathrm{L}^{-1}$ followed by Forested (6.17 to $9.95 \mathrm{mg} \mathrm{L}^{-1}$ ) while Kikafunda had the lowest values (range 6.64 to $8.74 \mathrm{mg} \mathrm{L}^{-1}$ ). The fish catch also generally followed the same trend where high DO levels correlated with higher fish catch.

The higher number of fishes in the Kikafunda and Rocky habitats is also attributed to the highly complex features including macrophytes, woody debris and stones respectively [20]. These structures provide substrate for food resources for benthivorous species and refuge against predatory fish and birds. This is in agreement with other previous studies which have shown that the predation risk is reduced in a range of complex habitat types including vegetated areas [31] whereas predation is very high in open water habitats. Complex habitats reduce predation risk because they interfere with location and capture of prey by predator and provide areas of shelter for the prey that are inaccessible to the predator [20]. This scores the importance of fringing vegetation along the shoreline of the lake.

Fish catches increased with decrease in water transparency. The main predator in Lake Victoria is the Nile perch; other fish seek for areas that can not be easily reached by the Nile perch. The catches are higher in turbid waters as this is associated with large algal biomass and possibly the fish could not easily see the gillnets. Chlorophyll-a levels depicts algal biomass in water, which is food for fish. Total nitrogen and Total phosphorus are the building blocks for food of fish (algae).

\subsection{Socio-Economic Parameters}

The communities living along the beaches in the three main research areas had most of their livelihood activities related to fishing. Although some of the household members could be engaged in non-fishing activities, such as, crop and livestock farming, shop keeping, among others, the main source of income was from fishing activities. As Table 7 shows, fishing activities included, owning a boat and or renting one, employment as boat crew in the fishing business. From the data, it was found that $47 \%$ of the residents have their principal occupation as fishing.

The respondents indicated that they catch a mixture of fishes $(60 \%)$ with the majority being the Nile perch. There is also some Clarius variety but Nile tilapia, which is most preferred, is very rare. When compared, the fishers around the mouths of River Yala have a better catch $(20$ to $40 \mathrm{Kg}$ per boat) while the River Kisat and Molasses Plant fish catch is only 3 to $16 \mathrm{Kg}$ per boat. The general scarcity and reduced fish from these fishing grounds was noted. What was very critical was the size of fish caught and the quality of fish particularly the taste. Juvenile fish was caught because of use of illegal fishing gears.

As for the taste of fish caught, the fishers from the River Kisat and Molasses fishing ground were categorical that the smell of sewerage and molasses were strong when eating Clarias. The poor water quality infiltrates the entire body of the fishes and other aquatic life thus posing a threat to their lives.

The issue of distance to proper fishing grounds ever on the increase for meaningful fishing was raised. That most fishing is at distances of 10 kilometers and beyond, sometimes even up to 60 kilometers. This poses a lot of risks to navigation and is also expensive. The worst is that it generates conflicts and opens room for piracy. Those who do not want to risk tend to stay behind, focusing on nearby grounds hence the catching of juvenile fish because of fishing near fish breeding areas and experiencing the real impact of water quality.

More than $50 \%$ of the respondents indicated that the disappearance of the fish, reduced income and ill health was probably due to the poor water quality. Although the fishers from River Yala mouth were not critically aware about the water quality situation, the ones of River Kisat and Molasses were clear in their minds that their waters have been destroyed by the effluents from the two areas. The heavy pollution arising from River Kisat and Molasses plant has a significant negative impact on the health of riparian communities and the aquatic lives in the nearby waters. From the taste of fish to the quality of drinking water and water for domestic use there are signs that the water quality is an issue of major concern. There is no doubt that it affects the quality of fish, fish abundance and the socio-economic conditions of the riparian communities [32].

\subsection{Implications of Water Quality and Fish Catch on Socio-Economics of Fisher Communities}

The turbid waters as depicted with low values of secchi depths in the study sites indicates that the inshore waters are poor for human and domestic use. This means that women and children have to move further towards the open waters to draw clearer 'cleaner' water posing a risk of drowning especially to the children, and exposure to dangerous aquatic 
organisms such as snakes in mats of water hyacinth plants. This further may increase chances of contaminating the water with urine and fecal materials.

The high levels of nutrients recorded in the study explain the eutrophic status of the waters. This is responsible for the frequent algal blooms. Some species of cyanobacteria, which make the largest portion of the blooms [2] produce toxins dangerous to man and other forms of aquatic life. The fish kills in some of the shore waters and health problems reported by the fisher communities may be attributed to these cyanobacterial toxins. Over-nutrified waters also lead to over growth of macrophytes, such as, the water hyacinth (Eicchornia crassipes) and other exotic species. The water hyacinth has been reported to have ecological and socioeconomic effects. It is known to entangle fish nets, it enters into boat engines leading to mechanical failure, it is used as a habitat by snails increasing the risk of bilharzia (schistosomiasis), harbors snakes, mosquitoes and its roots have been reported to be reservoirs for Vibrio cholerae the causative agent for cholera [2]. The loss of fish nets, frequent boat engine breakdowns, snake bites, high prevalence of bilharzia, malaria, cholera epidemics and other waterborne diseases that have been reported by the fisher communities maybe attributed the poor water quality manifested in the frequent algal blooms and the explosive invasions by the aquatic weeds. Algal blooms also cause unpleasant odours and taste in domestic water supplies, clog pump and machinery filters, increase chlorine demands for water disinfection, and necessitate more complex and expensive treatment processes [2]. These problems are further aggravated by poor sanitation, limited access to medical care, poor nutrition, and high mobility of the fisher folk. The increase in the incidence of diseases is attributed to rapid population growth of the lakeshore settlements due to the growth of the fishery, implying that the health infrastructure is by no mean commensurate to the huge population of fishers and fisher-dependent communities.

The declining fish catch may be the driver behind the use of illegal fishing gears and methods in order to increase their catch as a coping strategy. These illegal fishing gears and methods include use of under-sized nets (less than 2 inches) to catch even the immature fish, use of poison, explosives, and monofilament and seine nets. The reduced total length (TL) and weight of fish could be compelling fishermen to use undersized nets since they can not catch enough if they use the recommended sizes of fish nets. The rampant use of prohibited fish gear in addition destroys nursery grounds. This negatively impacts the fish recruitment process; besides, it fuels conflicts between fish managers and the Beach Management Units (BMUs) and within the BMU themselves as law abiding fishers fight it out with their counterparts using illegal fishing gear. The study sites which had high biological oxygen demand (BOD) values, such as, around River Kisat and the Molasses Plant, were also reported to have very low fish catch. High BOD values imply low dissolved oxygen (DO) levels in water. Fish and other aerobic organisms in water need optimum levels of oxygen for survival. If DO levels are reduced beyond intolerable levels, they either migrate to other areas or else they will die. This explains the poor catch reported by the fisher communities around the areas with high BOD values.

\section{CONCLUSION}

The findings suggest the importance of habitats types where fish species that are rare in the main lake were recorded. The survival of these fish species in these habitats is under threat from human activities, such as, preference for haplochromines as bait for Nile perch fishery and clearing of forests plus the fringing vegetation for agriculture and other developments. Water quality parameters like water transparency, dissolved oxygen, nitrogen, phosphorus and algal biomass greatly influenced fish composition, distribution and abundance. At the same time the water quality has a direct relationship with the health and socio-economic well being of communities living along those areas.

Creation and protection of closed areas, effluent control, riparian vegetation restoration programs, siltation control and adequate sustainable soil use are practices which could mitigate water quality deterioration and ensure fish species conservation in Thruston bay and other parts of the lake. Water quality parameters in Thruston bay are fairly good in relation to Yala and Geita study sites, and the other parts of Lake Victoria as reported in literature but deteriorating fast. Waste disposal should highly be discouraged so as to keep the bays relatively clean and reservoirs for fish species in the lake. An empowerment process among the riparian communities should be triggered and strengthened so that they could themselves participate in the decision making processes of fisheries management in order to be able to fight these ills to create favorable living environments and sustainable income bases. They must be in a position to lobby and participate in the evolution of appropriate laws that ensure sustainable livelihood. There should be promotion of the restoration of endemic fish species to cater for the local market as the commercial species, like the Nile perch, go to the international market. This will ensure food security, employment and ecological sustainability. There should be put in place an ecosystem-based management of the Lake Victoria fishery, which will include collaboration with other natural resourcebased sectors with an impact on fisheries resources. The use of indigenous knowledge of the riparian fisher communities in conjunction with scientific and modern methods and practices of fisheries conservation and management should be promoted. Enhancement of poverty alleviation programmes including micro-finance projects and fish farming could ease fishing pressure on the lake and uplift the livelihoods of the small scake fishing communities. Finally, provision of infrastructure including clean water, sanitation and health facilities to the fishing communities will reduce on the disease incidences and poverty eventually improving the standards of living of these marginalized communities.

\section{ACKNOWLEDGEMENT}

The study was financed by the Lake Victoria Research Initiative (VicRes). A number of NAFIRRI technicians and scientists provided technical and professional support. The Department of Zoology, Makerere University, provided invaluable support. The University of Maseno and Dar es Sa- 
laam staff is acknowledged together with local communities from within the three main study areas.

\section{REFERENCES}

[1] F. J. Muyodi and R. E. Hecky, "Water quality synthesis report for Uganda". Water Quality and Ecosystem Management, LVEMP, Ministry of Water and Environment, Republic of Uganda and World Bank, 2005.

[2] F. J. Muyodi, R. E. Hecky, J. M. Kitamirike and R. Odong, "Trends in health risks from water-related diseases and cyanotoxins in Ugandan portion of Lake Victoria basin". Lakes and Reservoirs: Res. and Manag., vol. 14, pp. 247-257, 2009.

[3] L. R. Varalakshmi and A. N. Ganeshamurthy, "Heavy metal contamination of water bodies, soils and vegetables in peri-urban areas of Bangalore city of India", in 19th World Congress of Soil Science, Soil Solutions for a Changing World, 1 - 6 August, Brisbane, Australia, 2010.

[4] P. B. O. Ochumba and D. I. Kibaara, "Observations on blue-green algal blooms in the open waters of Lake Victoria, Kenya", Afr. $J$. Ecol., vol. 27, pp. 23-34, 1989.

[5] D. Verschuren, T. C. Johnson, H. J. Kling, D. N. Edgington, P. R. Leavitt, E. T. Brown, M. R. Talbot and R. E. Hecky, "The chronology of human impact on Lake Victoria, East Africa". Proc. R. Soc. London, vol. B269, pp. 289-294, 2002.

[6] H. J. Kling, R. Mugidde and R. E. Hecky, "Recent changes in the phytoplankton community of Lake Victoria in response to eutrophication", in Great Lakes of the World: Food webs, health and integrity, Munawar, M. and R. E. Hecky, eds. Backhuys, Leiden, 2001, pp. 47-66.

[7] J. F. Talling and J. Lemoalle, "Ecological dynamics of tropical inland waters", Cambridge Univ. Press, 1998.

[8] R. E. Hecky, H. A. Bootsma, R. Mugidde and F. W. B. Bugenyi, Phosphorus pumps, nitrogen sinks, silicon drains: plumbing nutrients in the African Great Lakes, in The limnology, climatology and paleoclimatology of the East African lakes, T. C. Johnson and E. Odada, eds. 1996, pp. 205-224.

[9] R. Mugidde, R. E. Hecky, L. Hendzel and W. D. Taylor, "Pelagic nitrogen fixation in Lake Victoria, Uganda", J. Great Lakes Res., vol. 29(2), pp. 76-88, 2003.

[10] A. E. Williams, H. C. Duthie, and R. E. Hecky, "Water hyacinth in Lake Victoria: Why did it vanish so quickly and will it return?", Aquatic Bot., vol. 81, pp. 300-314, 2005.

[11] J. S. Balirwa, "Lake Victoria wetlands and the ecology of the Nile Tilapia, Oreochromis niloticus L". PhD thesis, Agricultural University of Wageningen, The Netherlands, 1998.

[12] P. H. Greenwood, "The fishes of Uganda", The Uganda Society, Kampala, $2^{\text {nd }}$ edition, 1966.

[13] J. Ogari, "The biology of Lates niloticus in the Nyanza Gulf of Lake Victoria (Kenya) with special reference to the food and feeding habits", M.S. thesis, University of Nairobi, 1984.

[14] G. Fryer, "The Lake Victoria Fisheries: Some facts and fallacies, Biological Conservation, vol. 5, pp. 305-308, 1973.

[15] P. B. Ochumba, O. M. Gophen and U. Pollinger, "Ecological changes in Lake Victoria after the invasion by Nile perch (Lates niloticus): The catchment, water quality and fisheries management", in Recent Trends of Research on Lake Victoria Fisheries, E. Okemwa, E. Wakwabi and A. Getabu, Eds, ICIPE, KMFRI, 1992, pp. 29-40.

[16] F. J. Muyodi, F. W. B. Bugenyi, and R. E. Hecky, "Experiences and Lessons Learned from Interventions in the Lake Victoria basin: the Case of Lake Victoria Environmental Management Project, Lakes \& Reservoirs: Res. and Manag., vol. 15(2), pp. 77-88, 2010.
[17] D. Calamari, M. O. Aketch and P. B. Ochumba, "Pollution of Winam Gulf, Lake Victoria, Kenya. A case study for preliminary risk assessment", Lakes and Reservoir: Res. Manag., vol. 1, pp. 89106, 1995.

[18] R. O. Anderson, and S. J. Gutreuter, "Length, weight and associated structural indices", in Fisheries Techniques, L. Nielsen and D. Johnson, Eds. American Fisheries Society, Bethesda, Maryland, 1983, pp. 284-300

[19] R. R. Parker, "Effects of formation on length and weight of fishes", Journal of the Fisheries Research Board of Canada, vol. 20, pp. 1441-1455, 1963.

[20] L. M. Campbell, J. S. Balirwa, D. G. Dixon, and R. E. Hecky, "Biomaginification of Mercury in fish from Thruston Bay, Napoleon Gulf, Lake Victoria (East Africa)", African J. Aquatic Sci., vol. 29(1), pp. 91-96, 2004.

[21] R. G. Wetzel, Ed., Limnology, 2nd Edition, Sanders College Publishing, USA, 1983.

[22] APHA, American Public Health Association, American Water Works Association, Water Environment Federation, L. S. Clesceri, A. E. Greenberg and A. D. Eaton, Eds., Standard Methods for the Examination of Water and Wastewater, $20^{\text {th }}$ ed., Washington, D.C., 1998.

[23] G. A. Boulenger, "Catalogue of the fresh-water fishes of Africa IV", Trustee Brit. Mus. (Nat. Hist), 1961.

[24] E. Trewavas, "The tilapiine fishes of the genera Sarotherodon, Oreochromis and Danakilia", Publ. Br. Mus. Nat. Hist., London, 1983.

[25] A. Muwanga and E. Barifaijo, "Impact of industrial activities on heavy metal loading and their physico-chemical effects on wetlands of Lake Victoria basin (Uganda)", African Journal of Science and Technology (AJST) Science and Engineering Series, Vol. 7(1), pp. 51-63, 2006.

[26] D. O. Ogoyi, M. Chacha, E. K. Nguu, C. O. Wasonga and P. M. Shiundi, "Effects of heavy metal pollution microalgea richness and diversity in Lake Victoria", in Lake Victoria Research Initiative proceedings, ISSN 2078-5933, 2009, pp. 193-210.

[27] R. E. Hecky and F. W. B. Bugenyi, "Hydrology and chemistry of African Great Lakes and water quality issues: Problems and solutions", Mitte. Internat. Verein. Limnol., vol. 23, pp. 45-54, 1992.

[28] A. Lappalainen, J. Tammi and A. Puro-Tahvanainen, "The effects of nickel smelters on water quality and littoral fish species composition in small watercourses in the border area of Finland, Norway and Russia”, Boreal Environment Research, vol. 12, pp. 455-466, 2007.

[29] S. B. K. Sekiranda, J. Okot-Okumu, F. W. B. Bugenyi M. and Nsega, "GIS-spatial comparisons of fish community structure in three bays with varying catchments of land use, Lake Victoria", in 2nd Eastern Africa ESRI User Conference (EAUC), September 1314, Kampala, Uganda, 2007, http://www.firi.go.ug/Publications/FIRRI\%20Papers/GIS_psartial_ compariosn_of_fish.pdf (Accessed 06/02/2011).

[30] L. Casatti, F. Langeani, A. M. Silva and R. M. C. Castro, "Stream fish, water and habitat quality in a pasture dominated basin, southeastern Brazil", Brazilian J. Biol. Vol. 66(2B), pp. 681-696, 2006.

[31] R. Ogutu-Ohwayo, "The decline in the native fishes of Lakes Victoria and Kyoga (East Africa) and the impact of the introduced species, especially the Nile perch, Lates niloticus and Nile tilapia, Oreochromis niloticus”, Environ. Biol. Fishes. Vol. 27, pp. 81-96, 1990.

[32] R. Abila, S. Walter, M. F. Ndonga, D. Otieno-Owiti, M. Barluenga and A. Meyer, "The role of the Yala swamp lakes in the conservation of Lake Victoria region haplochromine cichlids: Evidence from genetic and trophic ecology studies", Lakes and Reservoirs: Res. and Manag., vol. 13, pp. 95-104, 2008.

Received: December 06, 2010

Revised: March 07, 2011

Accepted: March 09, 2011

(C) Muyodi et al.; Licensee Bentham Open.

This is an open access article licensed under the terms of the Creative Commons Attribution Non-Commercial License (http://creativecommons.org/licenses/by-nc/3.0/g) which permits unrestricted, non-commercial use, distribution and reproduction in any medium, provided the work is properly cited. 